Bangladesh J. Bot. 37(1): 33-42, 2008 (June)

\title{
POLLEN MORPHOLOGY OF SOME TURKISH CAMPANULA SPP. AND THEIR TAXONOMIC VALUE
}

\author{
Ismuhan Potoglu Erkara*, Atila Ocak and Sevil Pehlivan ${ }^{1}$ \\ Department of Biology, Faculty of Science and Arts, Eskisehir Osmangazi University, \\ 26480, Meselik, Eskisehir, Turkey
}

Key words: Campanula, Pollen grains, Pollen morphology

\begin{abstract}
Detailed pollen morphological structures of 12 Turkish species of Campanula L., e.g. C. argaea, C. cymbalaria, C. glomerata subsp. hispida, C. latiloba subsp. latiloba, C. lyrata subsp. lyrata, C. olympica, C. persicifolia, C. pterocaula, C. rapunculoides subsp. cordifolia, C. rapunculus var. rapunculus, C. stricta var. stricta, C. pamphylica subsp. tokurii have been studied under light (LM) and scanning electron microscopes (SEM) for the first time. LM and SEM investigations show that the pollen grains of 12 taxa are more or less oblato-sphaeroidal, triporate (and/or tetraporate), tectum-scabrate, or with circular amb. The exine sculpture is granulate-scabrate in C. argaea, C. lyrata subsp. lyrata, C. stricta var. stricta, C. glomerata subsp. hispida and C. pamphylica subsp. tokurii; but those of C. cymbalaria, C. latiloba subsp. latiloba, C. olympica, C. persicifolia, C. pterocaula, C. rapunculoides subsp. cordifolia and C. rapunculus var. rapunculus are rugulate-scabrate.
\end{abstract}

\section{Introduction}

Campanula L. (Campanulaceae) is mainly a Northern hemisphere and Mediterranean genus and consists of 130 species of which 66 are endemic to Turkey (Damboldt 1978, Davis et al. 1988, Güner et al. 2001, Ocak 2003, Akcicek et al. 2005).

As pollen structures are micro-morphological attributes that can be used both to distinguish related taxa and also to integrate them into a common group. The morphological features of pollen grains of some of the Campanula species have been dealt with by several authors (Oybak and Pinar 1995, Perveen and Qaiser 1999, Ocak 2003, Akçiçek et al. 2005), and a detailed account of the pollen morphology of some Turkish Campanula species has been given by İnceoğlu (İnceoğlu 1976). The pollen characters of all Turkish Campanula species are yet to be studied in detail.

The purpose of this study is to determine through the use of LM and SEM, the extent to which morphological differences are well evaluated in 12 Turkish species of Campanula, five of which are endemic species to Turkey. This study also aims to throw light on the problematic aspects of taxonomy and evolution.

\section{Materials and Methods}

Pollen material was obtained from the Faculty of Science and Arts of Eskisehir Osmangazi University Herbarium (OUFE). For the purpose of LM investigations, pollen grains from herbarium materials were collected and prepared according to Wodehouse (1935) and Erdtman (1960). The pollen dimensions of all species were measured in such amounts that the resulting data followed Gaussian curves (Ozdamar 2004). These measurements are shown in Table 1. For SEM investigations, the unacetolyzed pollen grains were directly placed on stubs, sputter-coated with gold plate, and examined with a Jeol 5600 LV scanning electron microscope (Walker 1974a,b). The terminologies for pollen morphology proposed by Skvarla (1966), Erdtman (1969), Walker (1974a,b), Charpin et al. (1974) and Faegri and Iversen (1975) were employed.

\footnotetext{
${ }^{*}$ Correspondence author. E-mail: ismuhan@ogu.edu.tr. ${ }^{1}$ Department of Biology, Faculty of Science and Arts, Gazi University, 06500, Ankara, Turkey. E-mail: pehlivan@gazi.edu.tr
} 
Table 1. Companula specimens, their herbarium number and location of collection.

\begin{tabular}{|c|c|c|}
\hline $\begin{array}{l}\text { Campanula } \\
\text { taxa }\end{array}$ & $\begin{array}{l}\text { Herbarium } \\
\text { number }\end{array}$ & Location of collection \\
\hline C. argaea Boiss.\& Bal. & OUFE 11952 & Türkmen Baba-İdrisyayla, 1450 m \\
\hline C. cymbalaria Sm. in Sibth. \& Sm. & OUFE 11956 & B3 Eskişehir-Şelale Yolu, 1440 m \\
\hline $\begin{array}{l}\text { C. glomerata L. subsp. hispida } \\
\text { (Witasek) Hayek }\end{array}$ & OUFE 11957 & Türkmentepe \\
\hline C. latiloba A.D.C. subsp. latiloba & OUFE 11953 & $\begin{array}{l}\text { B3 Eskişehir, Sündiken Dağları, Kirazlıdere, } \\
\text { Alapınar Taycılar 1300-1500 m }\end{array}$ \\
\hline C. lyrata Lam. subsp. lyrata & OUFE 11954 & Sarıcakaya-Beyyayla 15 km, 1000 m \\
\hline C. olympica Boiss. & OUFE 11958 & Alapınar \\
\hline C. persicifolia L. & OUFE 11959 & B3 Eskişehir, Sarıcakaya Yolu \\
\hline C. pterocaula Hausskn. & OUFE 11955 & Karanlıkdere, $14-10 \mathrm{~m}$ \\
\hline $\begin{array}{l}\text { C. rapunculoides L. subsp. } \\
\text { cordifolia (C. Koch) Damboldt }\end{array}$ & OUFE 11960 & Kirazlıdere \\
\hline C. rapunculus L. var. rapunculus & OUFE 11961 & B3 Eskişehir, Mayıslar Köyü \\
\hline C. stricta L. var. stricta & OUFE 11962 & Türkmen Dağı-İdris Yayla \\
\hline $\begin{array}{l}\text { C. pamphylica subsp. tokurii } \\
\text { (A. Ocak) E. Akçiçek \& M. Vural }\end{array}$ & OUFE 9051 & $\begin{array}{l}\text { B3 Eskişehir, İdris Yayla, Sandıközü Köyü çevresi } \\
1450 \mathrm{~m} \text {. }\end{array}$ \\
\hline
\end{tabular}

\section{Results and Discussion}

LM and SEM investigations showed that pollen grains of 12 taxa were more or less oblatosphaeroidal, and triporate, but some grains were tetraporate, tectum-scabrate, with circular amb. The exine sculpture was granulate-scabrate in Campanula argaea, C. lyrata subsp. lyrata, C. stricta var. stricta, C. glomerata subsp. hispida and C. pamphylica subsp. tokurii; but in C. cymbalaria, C. latiloba subsp. latiloba, C. olympica, C. persicifolia, C. pterocaula, C. rapunculoides subsp. cordifolia and C. rapunculus var. rapunculus it was rugulate-scabrate.

In Campanula argaea (endemic), the pollen grains were triporate, oblato-sphaeroidal. The exine sculpture was granulate-scabrate, exine $1.35 \mu(\mathrm{W})$ and $0.95 \mu(\mathrm{E})$, tectum scabrate; amb circular, $26.20 \mu(\mathrm{W})$ and $21.24 \mu(\mathrm{E}), \mathrm{plg} / \mathrm{plt}=1.11 \mu(\mathrm{W})$ and $\mathrm{plg} / \mathrm{plt}=1.12 \mu(\mathrm{E})$. Annulus 0.09 $\mu$. Columella single-layered. The pollen surface was covered with supratectal spinules, which were $0.6 \mu \mathrm{m}$ in length and $0.5 \mu \mathrm{m}$ in width. One hundred and eight spinules were present in $100 \mu \mathrm{m}^{2}$ and the distance between two spinules was $1 \mu \mathrm{m}$. The operculum was entire with a smooth pore. The average operculum length was $4 \mu \mathrm{m}$ (Pl. 1, a-b, Tables 1-2).

In C. cymbalaria, the pollen grains were triporate, oblato-sphaeroidal, $\mathrm{P} / \mathrm{E}=0.97 \mu(\mathrm{W})$ and $\mathrm{P} / \mathrm{E}=0.95 \mu(\mathrm{E})$. The exine sculpture was rugulate-scabrate, exine $1.09 \mu(\mathrm{W})$ and $0.99 \mu(\mathrm{E})$, tectum scabrate; amb circular, $31.10 \mu(\mathrm{W})$ and $27.90 \mu(\mathrm{E}), \mathrm{plg} / \mathrm{plt}=1.1 \mu(\mathrm{W})$ and $\mathrm{plg} / \mathrm{plt}=1.24$ $\mu$ (E). Annulus $1.09 \mu$. The columella single-layered. The pollen surface was covered with supratectal spinules, which were $0.6 \mu \mathrm{m}$ in length and $0.5 \mu \mathrm{m}$ in width. One hundred and sixty spinules were present in $100 \mu \mathrm{m}^{2}$ and the distance between two spinules was $1 \mu \mathrm{m}$. The operculum was entire with a smooth pore. The average operculum length was $4 \mu \mathrm{m}$ (Pl.1, c-d, Tables 1-2). 

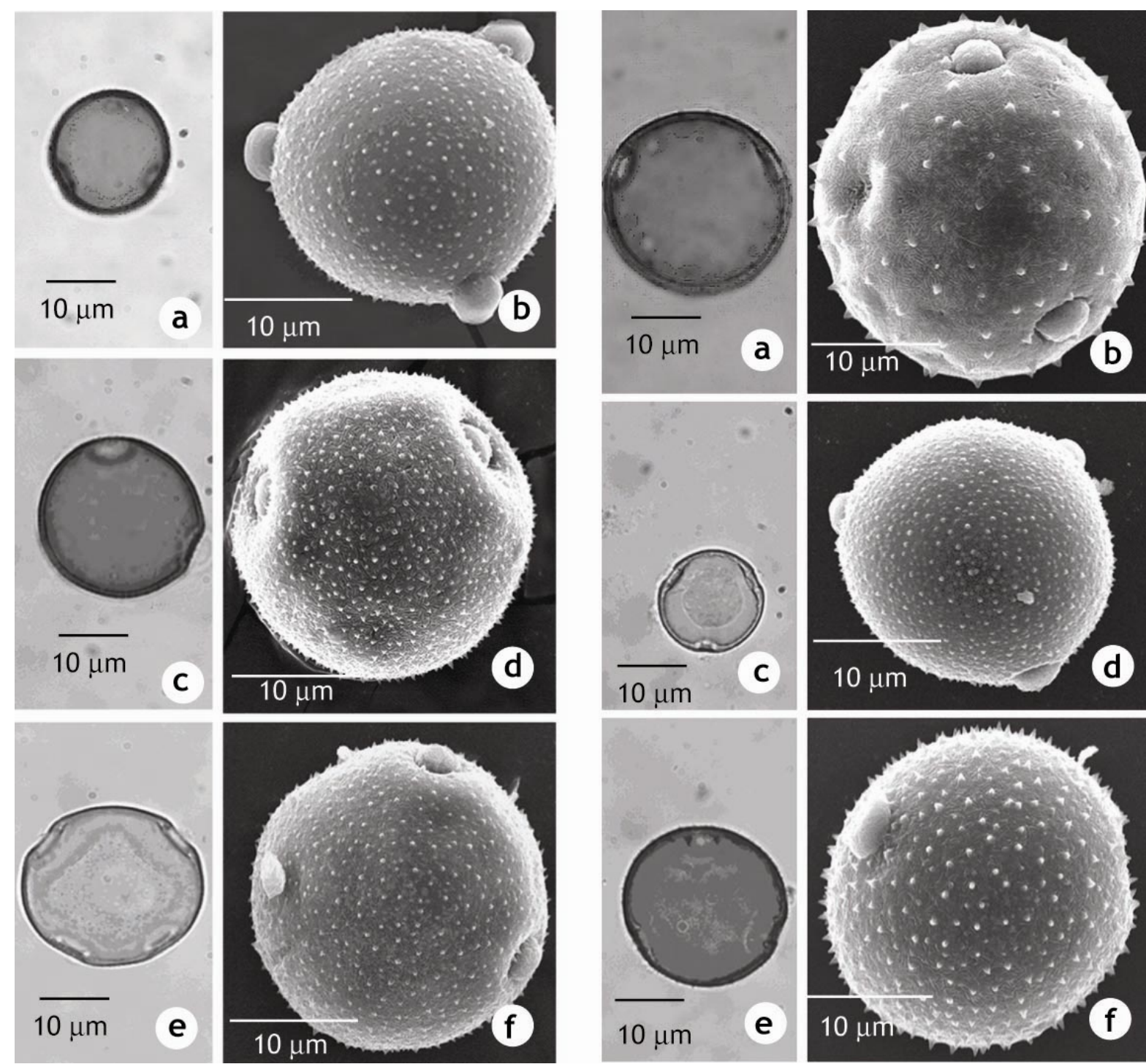

Plate 1
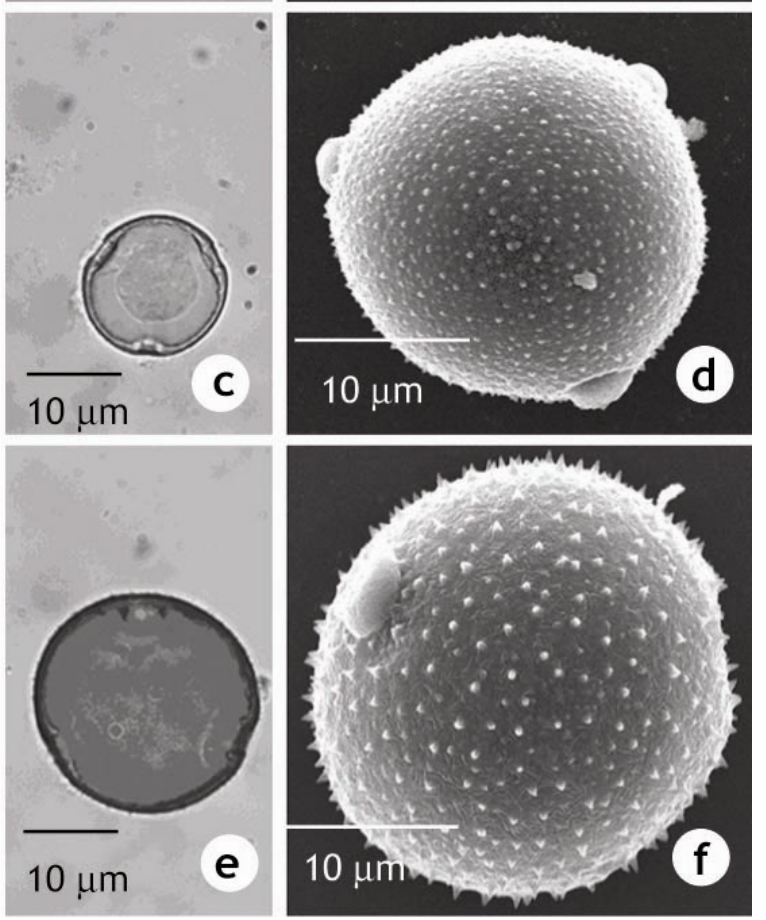

Plate 2

P1. 1. a-b: C. argeaea pollen photomicrographs; (a) Acetolysed (LM), (b) Non acetolysed (SEM), c-d: C. cymbalaria pollen photomicrographs; (c) Acetolysed (LM), (d) Non acetolysed (SEM); e-f: C. glomerata pollen photomicrographs; (e) Acetolysed (LM), (f) Non acetolysed (SEM), Scale $=10 \mu \mathrm{m}$.

P1. 2. a-b: C. latiloba subsp. latiloba pollen photomicrographs; (a) Acetolysed (LM), (b) Non acetolysed (SEM), c-d: C. lyrata subsp. lyrata pollen photomicrographs; (c) Acetolysed (LM), (d) Non acetolysed (SEM), e-f: C. olympica pollen photomicrographs; (e) Acetolysed (LM), (f) Non acetolysed (SEM); Scale $=10 \mu \mathrm{m}$. 
In C. glomerata subsp. hispida, the pollen grains were tri-tetraporate, $64 \%$ tetraporate, $36 \%$ triporate, oblato-sphaeroidal, $\mathrm{P} / \mathrm{E}=0.93 \mu(\mathrm{W})$ and $\mathrm{P} / \mathrm{E}=0.91 \mu(\mathrm{E})$. The exine sculpture was granulate-scabrate, exine $1.03 \mu(\mathrm{W})$ and $1.23 \mu(\mathrm{E})$, tectum scabrate, amb circular, $30.69 \mu(\mathrm{W})$ and $29.65 \mu(\mathrm{E}), \mathrm{plg} / \mathrm{plt}=1.13 \mu(\mathrm{W})$ and $\mathrm{plg} / \mathrm{plt}=1.14 \mu(\mathrm{E})$. Annulus $0.43 \mu$. The columella single-layered. The pollen surface was covered with supratectal spinules, which were $0.45 \mu \mathrm{m}$ in length and $0.30 \mu \mathrm{m}$ in width. One hundred and forty four spinules were present in $100 \mu \mathrm{m}^{2}$ and the distance between two spinules was $1 \mu \mathrm{m}$. The operculum was entire with a smooth pore. The average operculum length was $4 \mu \mathrm{m}$ (Pl. 1, e-f, Tables 2-3).

In C. latiloba subsp. latiloba (endemic), the pollen grains were triporate, oblato-sphaeroidal, $\mathrm{P} / \mathrm{E}=0.97 \mu(\mathrm{W})$ and $\mathrm{P} / \mathrm{E}=0.93 \mu(\mathrm{E})$. The exine sculpture was rugulate-scabrate, exine $1.22 \mu$ (W) and $1.10 \mu(E)$, tectum scabrate, amb circular, $31.10 \mu(\mathrm{W})$ and $27.90 \mu(\mathrm{E}), \mathrm{plg} / \mathrm{plt}=1.1(\mathrm{~W})$ and $\mathrm{plg} / \mathrm{plt}=1.24(\mathrm{E})$. Annulus $1.09 \mu$. The columella single-layered. The pollen surface was covered with supratectal spinules, which were $0.8 \mu \mathrm{m}$ in length and $1 \mu \mathrm{m}$ in width. Sixteen spinules were present in $100 \mu \mathrm{m}^{2}$ and the distance between two spinules was $4-5 \mu \mathrm{m}$. The operculum was entire with a smooth pore. The average operculum length was $4.8 \mu \mathrm{m}$ (Pl. 2, a-b, Tables 2-3).

In C. lyrata (endemic), the pollen grains were triporate, oblato-sphaeroidal, $\mathrm{P} / \mathrm{E}=0.96 \mu(\mathrm{W})$ and $\mathrm{P} / \mathrm{E}=0.94 \mu(\mathrm{E})$. The exine sculpture was granulate-scabrate, exine $1.04 \mu(\mathrm{W})$ and $1.10 \mu$ (E), tectum scabrate, amb circular, $26.44 \mu(\mathrm{W})$ and $23.06 \mu(\mathrm{E}), \mathrm{plg} / \mathrm{plt}=1.13 \mu(\mathrm{W})$ and $\mathrm{plg} / \mathrm{plt}=$ $1.19 \mu(\mathrm{E})$. Annulus $0.54 \mu$. The columella single-layered. The pollen surface was covered with supratectal spinules, which were $0.4 \mu \mathrm{m}$ in length and $0.5 \mu \mathrm{m}$ in width. One hundred and sixty eight spinules were present in $100 \mu \mathrm{m}^{2}$ and the distance between two spinules was $0.5-1 \mu \mathrm{m}$. The operculum was entire with a smooth pore. The average operculum length was $3.8 \mu \mathrm{m}$ ( $\mathrm{Pl} .2$, c-d, Tables 2-3).

In C. olympica, the pollen grains were triporate, oblato-sphaeroidal, $\mathrm{P} / \mathrm{E}=0.94 \mu(\mathrm{W})$ and $\mathrm{P} / \mathrm{E}$ $=0.92 \mu(\mathrm{E})$. The exine sculpture was rugulate-scabrate, exine $1.20 \mu(\mathrm{W})$ and $1.01 \mu(\mathrm{E})$, tectum scabrate, amb circular, $29.10 \mu(\mathrm{W})$ and $27.17 \mu(\mathrm{E}), \mathrm{plg} / \mathrm{plt}=1.20 \mu(\mathrm{W})$ and $\mathrm{plg} / \mathrm{plt}=1.16 \mu(\mathrm{E})$. Annulus $0.54 \mu$. The columella single-layered. The pollen surface was covered with supratectal spinules, which were $0.4 \mu \mathrm{m}$ in length and $0.5 \mu \mathrm{m}$ in width. One hundred spinules were present in $100 \mu \mathrm{m}^{2}$ and the distance between two spinules was $0.5-1 \mu \mathrm{m}$. The operculum was entire with a smooth pore. The average operculum length was $3.8 \mu \mathrm{m}$ (Pl. 2, e-f, Tables 2-3).

In C. persicifolia, the pollen grains were triporate, oblato-sphaeroidal, $\mathrm{P} / \mathrm{E}=0.97 \mu(\mathrm{W})$ and $\mathrm{P} / \mathrm{E}=0.96 \mu(\mathrm{E})$. The exine sculpture was rugulate-scabrate, exine $1.09 \mu(\mathrm{W})$ and $1.11 \mu(\mathrm{E})$, tectum scabrate, amb circular, $30.94 \mu(\mathrm{W})$ and $30.59 \mu(\mathrm{E}), \mathrm{plg} / \mathrm{plt}=1.16 \mu(\mathrm{W})$ and $\mathrm{plg} / \mathrm{plt}=$ $1.11 \mu(\mathrm{E})$. Annulus $0.09 \mu$. The columella single-layered. The pollen surface was covered with supratectal spinules, which were $1.12 \mu \mathrm{m}$ in length and $0.75 \mu \mathrm{m}$ in width. Twenty eight spinules were present in $100 \mu \mathrm{m}^{2}$ and the distance between two spinules was $4-5 \mu \mathrm{m}$. The operculum was entire with a smooth pore. The average operculum length was $3.8 \mu \mathrm{m}$ (Pl. 3, a-b, Tables 2-3).

In C. pterocaula (endemic), the pollen grains were triporate, oblato-sphaeroidal, $\mathrm{P} / \mathrm{E}=0.96 \mu$ (W) and $\mathrm{P} / \mathrm{E}=0.94 \mu(\mathrm{E})$. The exine sculpture was rugulate-scabrate, exine $1.13 \mu(\mathrm{W})$ and $1.17 \mu$ (E), tectum scabrate, amb circular, $29.11 \mu(\mathrm{W})$ and $27.72 \mu(\mathrm{E}), \mathrm{plg} / \mathrm{plt}=1.11 \mu(\mathrm{W})$ and $\mathrm{plg} / \mathrm{plt}=$ $1.17 \mu(\mathrm{E})$. Annulus $1.30 \mu$. The columella single-layered. The pollen surface was covered with supratectal spinules, which were $0.6 \mu \mathrm{m}$ in length and $0.9 \mu \mathrm{m}$ in width. Twelve spinules were present in $100 \mu \mathrm{m}^{2}$ and the distance between two spinules was $4-5 \mu \mathrm{m}$. The operculum was entire with a smooth pore. The average operculum length was $4 \mu \mathrm{m}$ (Pl. 3, c-d, Tables 2-3). 
In C. rapunculoides subsp. cordifolia, the pollen grains were triporate, oblato-sphaeroidal, $\mathrm{P} / \mathrm{E}=0.94 \mu(\mathrm{W})$ and $\mathrm{P} / \mathrm{E}=0.94 \mu(\mathrm{E})$. The exine sculpture was rugulate-scabrate, exine $1.24 \mu$ (W) and $1.05 \mu(E)$, tectum scabrate, amb circular $31.48 \mu(\mathrm{W})$ and $30.61 \mu(\mathrm{E}), \mathrm{plg} / \mathrm{plt}=1.13 \mu$ (W) and $\mathrm{plg} / \mathrm{plt}=1.12 \mu(\mathrm{E})$. Annulus $1.09 \mu$. The columella single-layered. The pollen surface was covered with supratectal spinules, which were $0.45-1.12 \mu \mathrm{m}$ in length and $0.40-0.65 \mu \mathrm{m}$ in width. Forty four spinules were present in $100 \mu \mathrm{m}^{2}$ and the distance between two spinules was 4-5 $\mu \mathrm{m}$. The operculum was entire with a smooth pore. The average operculum length was $4 \mu \mathrm{m}$ (Pl. 3, e-f, Tables 2-3).

In $C$. rapunculus var. rapunculus, the pollen grains were triporate, oblato-sphaeroidal, $\mathrm{P} / \mathrm{E}=$ $0.94 \mu(\mathrm{W})$ and $\mathrm{P} / \mathrm{E}=0.94 \mu(\mathrm{E})$. The exine sculpture was rugulate-scabrate, exine $1.14 \mu(\mathrm{W})$ and $0.98 \mu(\mathrm{E})$, tectum scabrate, amb circular, $27.58 \mu(\mathrm{W})$ and $26.94 \mu(\mathrm{E}), \mathrm{plg} / \mathrm{plt}=1.16 \mu(\mathrm{W})$ and $\mathrm{plg} / \mathrm{plt}=1.19 \mu(\mathrm{E})$. Annulus $0.22 \mu$. The columella single-layered. The pollen surface was covered with supratectal spinules, which were $0.45 \mu \mathrm{m}$ in length and $0.45 \mu \mathrm{m}$ in width. Seventy six spinules were present in $100 \mu \mathrm{m}^{2}$ and the distance between two spinules was 4-5 $\mu \mathrm{m}$. The operculum was entire with a smooth pore. The average operculum length was $4 \mu \mathrm{m}$ (Pl. 4 , a-b, Tables 2-3).

In C. stricta var. stricta, the pollen grains were triporate, oblato-sphaeroidal, $\mathrm{P} / \mathrm{E}=0.96 \mu(\mathrm{W})$ and $\mathrm{P} / \mathrm{E}=0.93 \mu(\mathrm{E})$. The exine sculpture was granulate-scabrate, exine $1.25 \mu(\mathrm{W})$ and $1.00 \mu$ (E), tectum scabrate, amb circular, $29.55 \mu(\mathrm{W})$ and $22.25 \mu(\mathrm{E}), \mathrm{plg} / \mathrm{plt}=1.14 \mu(\mathrm{W})$ and $\mathrm{plg} / \mathrm{plt}=$ $1.11 \mu(\mathrm{E})$. Annulus $0.43 \mu$. The columella single-layered. The pollen surface was covered with supratectal spinules, which were $0.45 \mu \mathrm{m}$ in length and $0.45 \mu \mathrm{m}$ in width. One hundred and sixteen spinules were present in $100 \mu \mathrm{m}^{2}$ and the distance between two spinules was $4-5 \mu \mathrm{m}$. The operculum was entire with a smooth pore. The average operculum length was $4 \mu \mathrm{m}$ ( $\mathrm{Pl} .4$, c-d, Tables 2-3).

In C. pamphylica subsp. tokurii (endemic), the pollen grains were triporate, oblatosphaeroidal, $\mathrm{P} / \mathrm{E}=0.95 \mu(\mathrm{W})$ and $\mathrm{P} / \mathrm{E}=0.91 \mu(\mathrm{E})$. The exine sculpture was granulate-scabrate, exine $1.23 \mu(\mathrm{W})$ and $1.00 \mu(\mathrm{E})$, tectum scabrate, amb circular, $26.22 \mu(\mathrm{W})$ and $22.88 \mu(\mathrm{E})$, $\mathrm{plg} / \mathrm{plt}=1.20 \mu(\mathrm{W})$ and $\mathrm{plg} / \mathrm{plt}=1.15 \mu(\mathrm{E})$. Annulus $0.76 \mu$. The columella single-layered. The pollen surface was covered with supratectal spinules, which were $0.36 \mu \mathrm{m}$ in length and $0.5 \mu \mathrm{m}$ in width. Eighty four spinules were present in $100 \mu \mathrm{m}^{2}$ and the distance between two spinules was 0.5-1 $\mu \mathrm{m}$. The operculum was entire with a smooth pore. The average operculum length was 4.5 $\mu \mathrm{m}$ (Pl. 4, e-f, Tables 2-3).

The results revealed that the pollen of 12 Campanula taxa were more or less oblatosphaeroidal, triporate, but some grains were tetraporate, tectate-scabrate, with circular amb.

The present LM and SEM study also provides a better understanding of the details of the pollen walls of 12 Campanula species. İnceoğlu $(1975,1976)$ determined the pollen morphologies of some Campanula in her studies, which reported faintly granulate ornemantation of the exine. But, the present investigation has revealed that the exine sculpture is granulate-scabrate in Campanula argaea, C. lyrata, C. stricta, C. glomerata and C. pamphylica subsp. tokurii, while C.cymbalaria, C. latiloba, C. olympica, C. persicifolia C. pterocaula, C. rapunculoides and C. rapunculus L. var. rapunculus showed rugulate-scabrate exine (Pls. 1-4).

It has been reported that aperture features and exine structures are among the essential criteria for the determination of the phylogenetic relationships of the species of Campanula (Kuprianova 1967, Cronquist 1968, Walker 1974a,b, Takhtajan 1980).

The present results are in agreement with those reported by Oybak and Pinar (1995), Perveen and Qaiser (1999), and Ocak (2003); but contradict with the results of İnceoğlu (1975, 1976). Although different species were investigated, there seems to be an agreement with the results of 

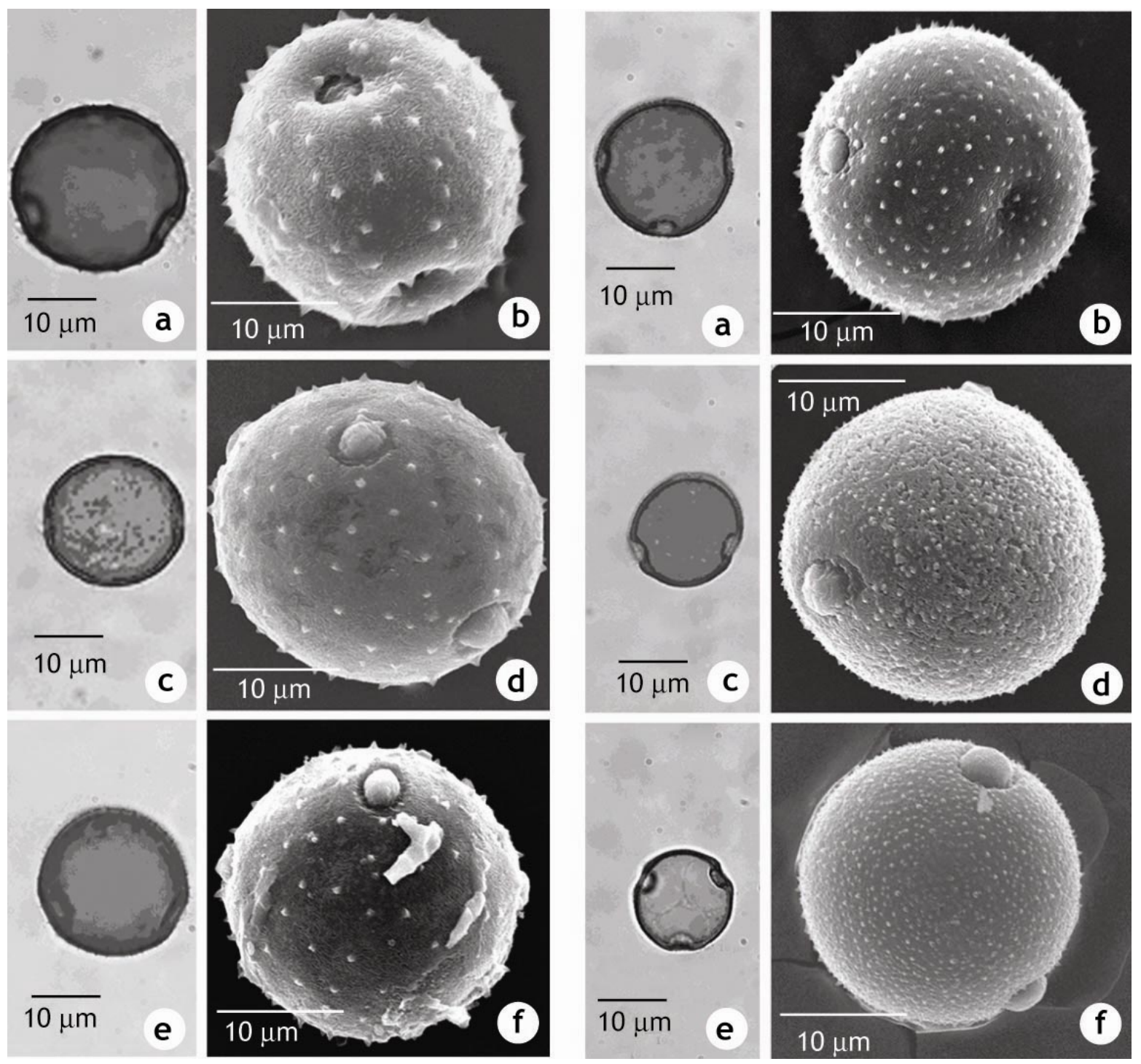

Plate 3

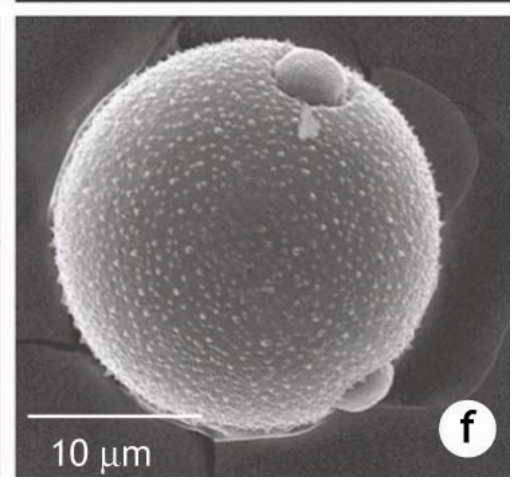

Plate 4

P1. 3. a-b: C. persicifolia pollen photomicrographs; (a) Acetolysed (LM), (b) Non acetolysed (SEM), c-d: C. pterocaula pollen photomicrographs; (c) Acetolysed (LM), (d) Non acetolysed (SEM); e-f: C. rapunculoides pollen photomicrographs; (e) Acetolysed (LM), (f) Non acetolysed (SEM), Scale $=10 \mu \mathrm{m}$.

Pl. 4. a-b: C. rapunculus var. rapunculus pollen photomicrographs; (a) Acetolysed (LM), (b) Non acetolysed (SEM); c-d: C. stricta pollen photomicrographs; (c) Acetolysed (LM), (d) Non acetolysed (SEM), e-f: C. pamphylica subsp. tokurii pollen photomicrographs; (e) Acetolysed (LM), (f) Non acetolysed (SEM); Scale $=10 \mu \mathrm{m}$. 
Oybak and Pinar (1995) in terms of the fact that the pollen bears spinules. These results seem to suggest that the spinule formation in the species of Campanula could be a genotypic characteristic.

In all types of Campanula pollens investigated, the operculum surface appeared to be mostly rough under the SEM. The morphological features of exine layers have been reported to be the features that best explain the nature of the phylogenetic relationship among the various taxa (Kuprianova 1967, Cronquist 1968, Walker 1974a,b, Takhtajan 1980). While LM revealed that Campanula only had a granulate structure, detailed SEM showed that they were constituted of both granules and spinules (Pls 1-4, Table 2).

Thus, difference in pollen morphology of twelve Turkish Campanula species could be a reflection of their genetic difference. Cronquist (1968) mentioned that in taxonomy, the sculpture types of pollens have valid morphological features.

\section{Acknowledgements}

The authors would like to thank Professor Dr. Cengiz Bayçu for providing them with SEM.

\section{References}

Akcicek, E., M. Vural, L. Açık and A. Çelebi. 2005. Notes on Campanula argaea group (Campanulaceae) in Turkey and related species. Ann. Bot. Fennici 42: 405-410.

Charpin, J., R. Surinyach and A.W. Frankland. 1974. Atlas of European allergenic pollens. Sandoz Editions, Paris, pp. 20-23.

Cronquist, A. 1968. The evolution and classification of the flowering plants. Thomas Nelson Ltd. Edinburgh.

Damboldt, J. 1978. Campanula L. In: Flora of Turkey and the East Aegean Islands. Vol. 6. Edinburgh Univ. Press, Edinburgh. pp. 2-64.

Davis, P.H., R.R. Mill and K. Tan. 1988. Campanula L. In: Flora of Turkey and the East Aegean Islands. Supplement 1, Vol. 10. Edinburgh Univ. Press, Edinburgh. pp. 177-180.

Erdtman, G. 1960. The acetolysis method. A revised description. Svensk. Bot. Tidskr. 54: 561-564.

Erdtman, G. 1969. Handbook of palynology, morphology, taxonomy, ecology. An introduction to the study of pollen grains and spores. Hafner Pub., New York.

Faegri, K. and J. Iversen. 1975. Textbook of pollen analysis. 3rd edn. Munksgaard, Copenhagen.

Güner, A., A. Dönmez, H. Duman, Y. Atlan, B. Yıldız and K. Tan. 2001. Campanula L. In: Flora of Turkey and the East Aegean Islands. Supplement 2, Vol. 11. Edinburgh Univ. Press, Edinburgh.

İnceoğlu, Ö. 1976. A study of some pollen grains of Campanulaceae by scanning electron microscopy. Communications de la Faculté des Sciences de l'Universite d'Ankara, Serie C2: Botanique 20: 31-39.

Kuprianova, A. 1967. Apertures of pollen grains and their evolution in angiosperms. Paleobot. Playnology 3 : 73-80.

Ocak, A. 2003. A new species of Campanula L. (Campanulaceae) from Central Anatolia, Turkey. Israel J. Plant Sci. 51: 321-325.

Oybak, E. and M. Pinar. 1995. Pollen morphology of some Turkish Campanula L. species (Campanulaceae). Turkey J. Bot. 19: 577-580.

Ozdamar, K. 2004. Paket Programlar ile statistiksel Veri Analizi 5. baski. 535 S. Kaan Kitapevi, Eskişehir, Türkiye.

Perveen, A. and M. Qaiser. 1999. Pollen Flora of Pakistan- XIII. Campanulaceae. Turkey J. Bot. 23: 45-51.

Skvarla, J.J. 1966. Techniques of pollen and spore electron microscopy. I. Staining, dehydration and embedding. Oklah. Geol. Notes 26: 179-186.

Takhtajan, A.L. 1980. Outline of the classification of flowering plants (Magnoliophyta). Bot. Rev. 46.

Walker, J.W. 1974a. Evolution of exine structure in the pollen of primitive Angiosperms. Amer. J. Bot. 61: 891-902.

Walker, J.W. 1974b. Aperture evolution in the pollen of primitive Angiosperms. Amer. J. Bot. 61: $1112-$ 1137.

Wodehouse, R.P. 1935. Pollen Grains. McGraw Hill., New York. 